\title{
How Does Costco Win Customer Satisfaction: A Case Study of the South of Taiwan
}

\author{
Shiau Pei Shih, Szuchiang Yu, and Feng Ju Yen
}

\begin{abstract}
This study aimed to investigate how Costco Taiwan can win consumers' supports and satisfactions in a such competitive market today. As the economy has rapidly changed and developed, consumers' awareness are rising quickly, it is getting harder and harder to gain customers' satisfactions for those wholesale stores. The purpose of this study is to understand if there is the positive relationship between the experiential marketing strategies and the customers' satisfactions for Costco wholesale business. In this study, 120 copies of questionnaires were distributed to Costco wholesale club members in the southern areas of Taiwan, and 120 valid copies of questionnaires were analyzed. According to the results of the statistics analysis, Cronbach's $\alpha=.902$. The results showed that act experiential marketing had a positive correlated relationship with customers' satisfactions.
\end{abstract}

Index Terms-Experiential marketing, customer satisfaction, warehouse stores, Costco.

\section{INTRODUCTION}

As economic development, Taiwan has been moving into business and industry-based economy, which gradually enhances people's living standards and quality, also change people's consumption patterns. Since 1989, Makro, Carrefour, RT-Mart, Geant, Costco and many other chain stores from home and abroad have entered the Taiwan retail and wholesale market.

Costco opened its first wholesale store in Kaohsiung , Taiwan in 1997; now there are a total of nine stores, located in Taipei (2 stores), Taoyuan (1 store), Hsinchu (1 store), Taichung (1 store), Tainan (1 store) and Kaohsiung (2 stores), also Chiayi (1 store) was grand opening on this August in 2013. In fact, the number of Costco wholesale store has been established increasing in Taiwan, and the turnover has been relatively improving, the average annual turnover of a single store is $\$ 5$ billion in 2012 .

Liu Jinhong and Hung Wei-liang (2007) claimed that the wholesale store with a "one-stop shopping, leisure, entertainment, information, a big parking lot" as the necessary competitive situations in the market. After many years of wholesale business development, customer is no longer satisfied to receive the information provided by the seller only, but also need to go through the way of experiential shopping first, then they can do comparison and make a purchasing decision later [1].

Cardozo (1965) proposed the concept of customer satisfaction, he considered the customer satisfaction

Manuscript received October 21, 2013; revised December 24, 2013.

Shiau Pei Shih is with the Far East University, Taiwan (e-mail: jenniferfeu@gmail.com). enhancement can increase customers' buying behavior [2]. Woodruff and Bobert (1993) and Schmitt (1999) believed that the value of experience and customer satisfaction are closely related. Kotler (2006) explained that buyers' satisfaction depends on if the goods or services can meet their expectations after purchasing or experiencing [3]-[5].

\section{LITERATURE REVIEW}

\section{A. Act Experience}

See Table I, Pine and Gilmore (1998) mentioned that act experience for consumers was to create an unforgettable service activities, companies must to serve the commodity as a prop around consumers and to create wonderful memories of activities to consumers as well in the " experience economy " [6].

Schmitt (1999) explained the definition of act experience was the experience usually occurs by direct events, observation or participation no matter the event was real, fantasy or a virtual which have a significant effect of positive experience value [4].

TABLE I: ACT EXPERIENCE

\begin{tabular}{|c|c|c|}
\hline Year & Scholars & "Definition \\
\hline 1998 & Pine \&Gilmore & $\begin{array}{l}\text { To create a memorable and unforgettable } \\
\text { experience [6]. }\end{array}$ \\
\hline 1999 & Schmitt & $\begin{array}{l}\text { The experience usually occurs by direct } \\
\text { events, observation or participation [4]. }\end{array}$ \\
\hline 2006 & Lin,Xinli & $\begin{array}{l}\text { Related to consumer experience and } \\
\text { situational factors such as the senses, } \\
\text { emotions, thinking, and action [8]. }\end{array}$ \\
\hline 2008 & $\begin{array}{l}\text { Hung, Kun } \\
\text { Chiao }\end{array}$ & $\begin{array}{l}\text { Act experience was caused by the combination } \\
\text { of memories and feelings of the body and soul } \\
\text { at a particular time [7]. }\end{array}$ \\
\hline 2010 & Wen & $\begin{array}{l}\text { The results showed that the senses, act, think } \\
\text { were associated, act experience and } \\
\text { customer satisfaction had a positive } \\
\text { relationship [9]. }\end{array}$ \\
\hline
\end{tabular}

According to Hung, Kun-Chiao (2008), the study showed that act experience was not spontaneous but induced by certain situations; individual operation experience was caused by the combination of memories and feelings of the body and soul at a particular time. It's like a new product for customers to try, even they do not know the product is good or bad, they still want to have a new experience [7].

Therefore, industry can take advantage of act experience to improve the customer satisfaction. Not only to focus on the moment of customer experience, but also to pay attention to customers' feeling before and after act experience. So how to utilize commercial advertising, product information and 
promotions to increase customer satisfactions is a key factor to act experience.

\section{B. Customer Satisfaction}

See Table II, Cardozo (1965) proposed the concept of customer satisfaction, he considered that the raising of customers' satisfactions can increase their purchasing behaviors, further it would also affect customer to purchase other products in store [2]. Fornell (1992) pointed out that customer satisfaction was created by customers' buying experience [10].

Chi, Wen Hai (2007) thought customers' satisfaction coming from the result before or after purchasing or serving, which meant the better service the higher customers' satisfaction [11]. Lee, Wen- Ling (2009) believed that customers' satisfaction was an emotional response by product expectations, products performance and the quality of customer services, as in [12].

This study was approved by the literature, and we found that whether the customer satisfaction good or bad all depending on if service providers meet their customer expectations.

TABLE II: CUSTOMER SATISFACTION

\begin{tabular}{|c|c|c|}
\hline Year & Scholar & Definition \\
\hline 1965 & Cardozo & $\begin{array}{l}\text { First scholar proposed the concept of customer } \\
\text { satisfaction [2]. }\end{array}$ \\
\hline 1980 & Oliver & $\begin{array}{l}\text { Customer satisfaction was decided by the results } \\
\text { of expectations from product or service [13]. }\end{array}$ \\
\hline 1992 & Fornell & $\begin{array}{l}\text { Customer satisfaction was created by customers' } \\
\text { buying experience }[10] .\end{array}$ \\
\hline 2002 & Wang & $\begin{array}{l}\text { Customer satisfaction can be seen as an } \\
\text { identification of customer expectation [14]. }\end{array}$ \\
\hline 2006 & Kotler & $\begin{array}{l}\text { The performances of goods can meet customers' } \\
\text { expectations [15]. }\end{array}$ \\
\hline 2007 & ChiWen Hai & $\begin{array}{l}\text { The better service the higher customers' } \\
\text { satisfactions [11]. }\end{array}$ \\
\hline 2009 & Yin & $\begin{array}{l}\text { The expected cognitive level is consistent before } \\
\text { and after services or goods purchased [16]. }\end{array}$ \\
\hline 2011 & Lin Jun & $\begin{array}{l}\text { The reflection for overall satisfaction was caused } \\
\text { by the consistent expectations after consuming } \\
\text { [17]. }\end{array}$ \\
\hline 2012 & Lin Yongrui & $\begin{array}{l}\text { Customer satisfaction was decided by the } \\
\text { customer expectations and what they've actually } \\
\text { gotten [18]. }\end{array}$ \\
\hline
\end{tabular}

TABLE III: THE ACT EXPERIENCE AND CUSTOMER SATISFACTION

\begin{tabular}{lll}
\hline \hline Year & Scholar & Definition \\
\hline 1993 & $\begin{array}{l}\text { Woodruff \& } \\
\text { Bobert }\end{array}$ & $\begin{array}{l}\text { Act experience and satisfaction were closely } \\
\text { linked. The better experience can bring higher } \\
\text { customer satisfaction [3]. }\end{array}$ \\
2004 & $\begin{array}{l}\text { Hong,Sheng } \\
\text { Hong }\end{array}$ & $\begin{array}{l}\text { There were a highly positive relationship } \\
\text { between act experience marketing and customer } \\
\text { satisfaction [19]. }\end{array}$ \\
& Yin & $\begin{array}{l}\text { Act experience can be positive to customer } \\
\text { satisfaction, there was a positive correlation. } \\
\text { between experiential marketing and customer } \\
\text { satisfaction [16]. } \\
\text { The results showed the act experience and the } \\
\text { customer satisfaction had a positive relationship } \\
\text { [20]. }\end{array}$ \\
\hline \hline
\end{tabular}

\section{Act Experience and Customer Satisfaction}

See Table III, Woodruff and Bobert (1993) declared that the customers' act experience and customer satisfaction were closely related [3]. Better experience can bring higher customer satisfaction. Hong, Hongsheng (2004) [19] explored that the experiential marketing directly affected customer satisfaction. The experiential modules of act experience had a positive relationship with customer satisfaction. Tsai, Ruiwen (2010) expressed that there was a positive correlation between act experience and customer satisfaction [20].

\section{RESEARCH METHODS}

This study was conducted to investigate the relationship between act experience and customers' satisfactions. The participants responded to the questionnaire items with the assurance; hence, data were collected at one point in time, the response were more truthful than other research methods such as personal interviews (Babbie, 1990) [21].

\section{A. Research Framework}

According to the chapters of introduction and literature review, we wanted to explore the influence of act experience on customer satisfaction, so the hypotheses was if there was a positive relationship between the act experience and customer satisfaction (See Fig. 1). In this study, the data were collected from July to September, 2013.

As Schreiber's (2006) rule of thumb is 5 to 10 observations per item for a test of 12 parameters [22], the sample size for the present study was set at 120 . A total of 120 questionnaires were distributed and returned. All of these respondents were in a sample appropriate for further statistical analyses. Demography, reliability, independent $t$ test and the correlation analysis were analyzed by SPSS12.0.

\section{DATA ANALYSIS}

\section{A. The Demographic Characteristics}

From the Table IV, the percentage of males was $49.0 \%$, females accounted for $51.0 \%$. It didn't differ much about gender in Costco warehouse club stores in the south of Taiwan. The majority age was under 30 years old $(77.5 \%)$; the majority monthly income was less than $\$ 30,000$ (69.2\%).

\section{B. Reliability}

Scale reliability coefficient refers to the consistency or stability, reliability is a good indicator in the same operation was repeated under similar conditions. Nunnally (1978) suggested that Cronbach's $\alpha$ values is at least greater than 0.70 in the general study [23]. In the present study, the results were shown in Table $\mathrm{V}$, all of composite reliability scores are higher than 0.7 .

\section{Independent Sample T-Test}

In Table VI, there was sufficient evidence to show that the female customers had the stronger feeling of "open hours can meet my needs" than male in the dimension of "act experience". Male has more sense than female on the rest of 
items of the dimension of "act experience", especially for "regular product information". Also, there was a sufficient evidence to show that the male customers had higher satisfaction than female in the dimension of "customer satisfaction".

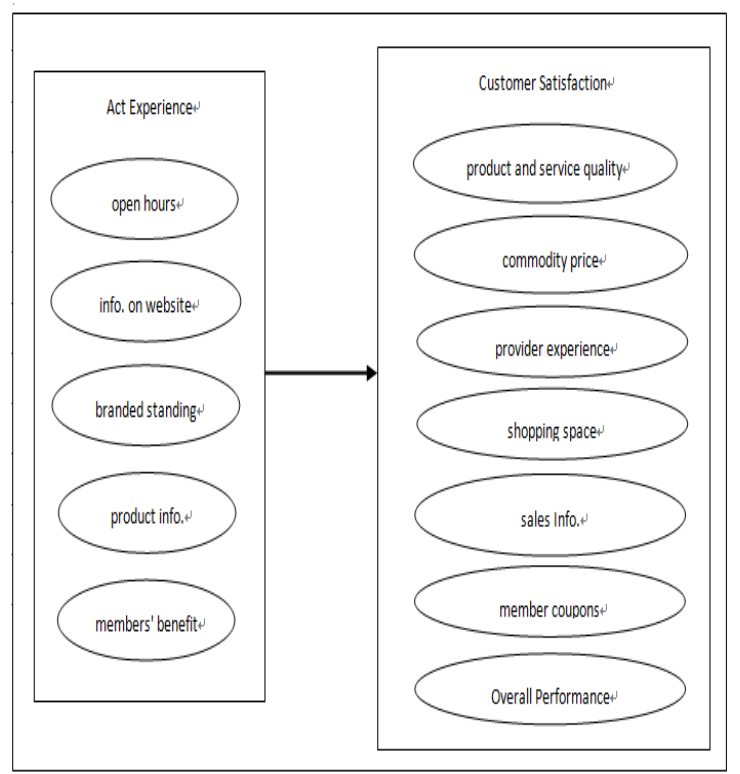

Fig. 1. Research framework.

TABLE IV: DESCRIPTION ANALYSIS

\begin{tabular}{|c|c|c|c|}
\hline Factor & Range & $\begin{array}{c}\text { Number of } \\
\text { people }\end{array}$ & $\begin{array}{l}\text { Cumulative } \\
\text { percentage }\end{array}$ \\
\hline \multirow[t]{2}{*}{ Gender } & Male & 59 & $49.00 \%$ \\
\hline & Female & 61 & $100.00 \%$ \\
\hline \multirow[t]{4}{*}{ Age } & $\begin{array}{l}\text { Under } 30 \text { years } \\
\text { old }\end{array}$ & 93 & $77.5 \%$ \\
\hline & $31-40$ years & 12 & $87.5 \%$ \\
\hline & $41-50$ years & 9 & $95.0 \%$ \\
\hline & $\begin{array}{l}\text { Above } 51 \text { years } \\
\text { old }\end{array}$ & 6 & $100.0 \%$ \\
\hline \multirow[t]{5}{*}{ Income } & $\begin{array}{l}\text { Less than NT\$ } \\
30,000\end{array}$ & 83 & 69.2 \\
\hline & $\begin{array}{l}\text { NT } \$ 30,001 \text { to } \\
40,000\end{array}$ & 20 & 85.8 \\
\hline & $\begin{array}{l}\text { NT } \$ 40,001 \text { to } \\
50,000\end{array}$ & 8 & 92.5 \\
\hline & $\begin{array}{l}\text { NT\$50,001 to } \\
60,000\end{array}$ & 3 & 95.0 \\
\hline & $\begin{array}{l}\text { More than NT \$ } \\
60,001\end{array}$ & 6 & 100.0 \\
\hline
\end{tabular}

\begin{tabular}{lcc}
\multicolumn{3}{c}{ TABLE V: CREDIBILITY ANALYSIS } \\
\hline \hline & $\begin{array}{c}\text { Cronbach's Alpha } \\
\text { Value }\end{array}$ & $\begin{array}{c}\text { Number of } \\
\text { Items }\end{array}$ \\
\hline $\begin{array}{l}\text { Act Experience } \\
\begin{array}{l}\text { Customer } \\
\text { Satisfaction }\end{array}\end{array}$ & 0.902 & 5 \\
\hline \hline
\end{tabular}

TABLE VI: T-TEST OF GENDER, ACT EXPERIENCE AND CUSTOMER SATISFACTION

\begin{tabular}{|c|c|c|c|c|c|}
\hline \multirow[t]{2}{*}{ Dimensions } & \multirow[t]{2}{*}{ Q Questions } & \multicolumn{2}{|c|}{ Mean } & \multirow{2}{*}{$\begin{array}{c}\mathrm{t} \\
\text { value }\end{array}$} & \multirow{2}{*}{$\begin{array}{c}\mathrm{P} \\
\text { value }\end{array}$} \\
\hline & & $\begin{array}{l}\text { Male } \\
N=59\end{array}$ & $\begin{array}{l}\text { Female } \\
N=61\end{array}$ & & \\
\hline \multirow[t]{5}{*}{$\begin{array}{l}\text { Act } \\
\text { Experience }\end{array}$} & $\begin{array}{l}\text { 1. Open hours } \\
\text { can meet my } \\
\text { needs }\end{array}$ & 4.10 & 4.21 & 1.686 & $.004 *$ \\
\hline & $\begin{array}{l}\text { 2. Each store } \\
\text { add. and info. } \\
\text { on the website }\end{array}$ & 4.34 & 4.25 & 2.186 & $.002 *$ \\
\hline & $\begin{array}{l}\text { 3. Providing } \\
\text { branded } \\
\text { standings }\end{array}$ & 4.43 & 4.16 & 1.752 & $.001 *$ \\
\hline & $\begin{array}{l}\text { 4. Regularly } \\
\text { product } \\
\text { information }\end{array}$ & 4.37 & 3.39 & 2.439 & $.002 *$ \\
\hline & $\begin{array}{l}5 . \\
\text { Membership } \\
\text { cards have } \\
\text { more benefits }\end{array}$ & 4.35 & 4.25 & 1.586 & $.002 *$ \\
\hline \multirow[t]{7}{*}{$\begin{array}{l}\text { Customer } \\
\text { Satisfaction }\end{array}$} & $\begin{array}{l}\text { 1. Product and } \\
\text { service } \\
\text { quality }\end{array}$ & 4.31 & 3.92 & 2.946 & $.007 *$ \\
\hline & $\begin{array}{l}\text { 2. Commodity } \\
\text { price }\end{array}$ & 4.15 & 3.72 & 2.939 & $.002 *$ \\
\hline & $\begin{array}{l}\text { 3. Provider } \\
\text { experience }\end{array}$ & 4.36 & 3.75 & 2.984 & .451 \\
\hline & $\begin{array}{l}\text { 4. Shopping } \\
\text { space }\end{array}$ & 4.34 & 4.03 & 2.980 & $.001 *$ \\
\hline & $\begin{array}{l}\text { 5. Clear sales } \\
\text { information }\end{array}$ & 4.27 & 3.74 & 4.379 & .247 \\
\hline & $\begin{array}{l}\text { 6. Member } \\
\text { coupons }\end{array}$ & 4.07 & 3.61 & 4.378 & .876 \\
\hline & $\begin{array}{l}\text { 7. Overall } \\
\text { Performance }\end{array}$ & 4.25 & 3.92 & 2.368 & .926 \\
\hline
\end{tabular}

\section{Correlation Analysis}

Pearson correlation analysis was used for two other dimensions: "act experience" and "customer satisfaction", the result showed coefficients were positive correlation of .506 (see Table VII) and reached significant level $(p<0.01)$, which indicated that two dimensions were significant correlated to each other. It explained that the better act experience, the higher customer satisfaction.

TABLE VII: THE CORRELATION BETWEEN ACT EXPERIENCE AND CUSTOMER SATISFACTION

\begin{tabular}{|c|c|c|c|}
\hline & & $\begin{array}{c}\text { Act } \\
\text { Experience }\end{array}$ & $\begin{array}{c}\text { Customer } \\
\text { Satisfaction }\end{array}$ \\
\hline \multirow[t]{3}{*}{ Act Experience } & $\begin{array}{l}\text { Pearson } \\
\text { correlation }\end{array}$ & 1 & $0.506(* *)$ \\
\hline & $\begin{array}{l}\text { Significant } \\
\text { (2-tailed) }\end{array}$ & & 0.000 \\
\hline & Number & 120 & 120 \\
\hline \multirow[t]{3}{*}{$\begin{array}{l}\text { Customer } \\
\text { Satisfaction }\end{array}$} & $\begin{array}{l}\text { Pearson } \\
\text { correlation }\end{array}$ & $0.506(* *)$ & 1 \\
\hline & $\begin{array}{l}\text { Significant } \\
\text { (2-tailed) }\end{array}$ & 0.000 & \\
\hline & Number & 120 & 120 \\
\hline
\end{tabular}

\section{CONCLUSIONS AND RECOMMENDATIONS}

According to statistical analysis results in this study, the majority customers was females, age under 30 years old and the average monthly income less than NT\$30,000. We can 
understand there was a significant difference between male and female on each dimension of act experience and customer satisfaction. We also can know that the correlation coefficients between act experience and customer satisfaction was positive correlated, and the coefficient ratio was .506 which reached the significant level $(p<0.01)$. From the result of study, we can tell the female customer satisfaction was much lower than the male customers. So we suggest Costco wholesale store should increase the attractiveness of female commodities for improving female customers' act experience for increasing their satisfactions in the future.

\section{REFERENCES}

[1] J. H. Liu and W. L. Hung, "The key factors of customer satisfaction in the wholesale discount stores," M.S. thesis, Dept. Bus. Admin National Chin-Yi Univ. of Tech., Taichung, Taiwan, 2007.

[2] R. N. Cardozo, "Experimental study of customer effort, expectation and satisfaction," Journal of Marketing Research, vol. 2, no. 8, pp. 244-249, Aug. 1965.

[3] R. Woodruff and B. Bobert, "Develop and applying consumer satisfaction knowledge: Implications for future research," Journal of Consumer Satisfaction, Dissatisfaction and Complaining Behavior, vol. 6, pp. 1-11, Aug. 1993.

[4] B. H. Schmitt, Experiential Marketing: How to Get Customer to Sense, Feel, Think, Act, and Relate to Your Company and Brands, New York, NY: The Free Press, 1999, ch. 1, pp. 160-161.

[5] P. Kotler and K. L. Keller, Marketing Management, 13th ed., NY: Pearson Prentice Hall, 2009, ch. 11, pp. 378-414.

[6] B. J. Pine and J. H. Gilmore, "Welcome to the experience economy," Harvard Business Review, vol. 76, no. 4, pp. 76-97, Jul.-Aug. 1998.

[7] H. K. Qiao, "Experiential marketing model used in public transportation empirical study - A case study of Taiwan high speed rail corporation,” M. S. thesis, Dept. International Business, Hsuan Chuang University, Hsinchu, Taiwan, 2008.

[8] X. L. Lin, P. Y. Lin, Y. T. Xie, X. Wu, H. C. N. Ya, and P. Z. C. Chien, "Experiential marketing perspective from theme restaurants consumer situational factors research, tourism and leisure," in Proc. of the Hospitality Industry Sustainability Symposium , Kaohsiung, 2006, pp. $1-8$.

[9] W. C. Wen, "The effect of customer testimonial on consumers' attitude - The case of beauty product," M. S. thesis, Dept. of Business Administration, National Cheng Kung Univ., Tainan, Taiwan, 2010.

[10] C. Fornell, "A national customer satisfaction barometer: The Swedish experience," Journal of Marketing, vol. 56, no. 1, pp. 6-21, Jan. 1992.

[11] C. W. Hai, Z. R. Yang, C. S. He, "The news website service quality, customer satisfaction and loyalty relationship research," Journal of Quality Technology, vol. 14, no. 3, pp. 1-15, Sep. 2007.

[12] W. L. Lin, "The network service quality on satisfaction bookstore and purchase intention - A case study of bookstore network in Taipei, Taiwan,” M.S. thesis, Dept. Bus. Admin. Tatung Univ., Taichung, Taiwan, 2008.

[13] R. L. Oliver, "A cognitive model of the antecedents and consequences of satisfaction decisions," Journal of Marketing Research, vol. 17, no. 4, pp. 460-469, Nov. 1980.

[14] C. S. Wang, "Interrelationships between brand equity, brand preference and purchase intention: A study of causes and effects on brand equity," M.S. thesis, Dept. of Business Administration, National Cheng Kung Univ., Tainan, Taiwan, 2002
[15] P. Kotler, "New directions in museums, visitor experience, and marketing," in Proc. the Museum Marketing Symposium, Taipei, 1998 , pp. 23-43.

[16] C. L. Yin, "The study of the relationship among experiential marketing, experiential value, customer satisfaction and customer loyalty - A case study of shangralis leisure farm in Yilan city, Taiwan," M.S. thesis, Dept. Bus. Admin., National Chengchi Univ., Yilan, Taiwan, 2009.

[17] P. C. Lin, "The correlation analysis of experiential marketing, customer satisfaction and loyalty - A case study of consumers' sports goggles in Taipei area," M. S. thesis, Dept. Sport and Leisure, National Taiwan Normal Univ., Taipei, Taiwan, 2011.

[18] Y. R. Lin, "The study of service personnel empathy for business image, customer satisfaction and repurchase intention- A case study of chain convenience store," M.S. thesis, Dept. MIS., Yih Shou Univ., Kaohsiung, Taiwan, 2012

[19] H. S. Hong, "Experiential marketing and relationship marketing on customer value and customer satisfaction impact of research Research,” M.S. thesis, Dept. Bus. Admin., National Kaohsiung Univ. of Applied Sciences, Kaohsiung, Taiwan, 2004.

[20] J. W. Tsai, "The study of the relationship among experiential marketing, experiential value and customer satisfaction, customer loyalty - A case study of Denwell, Taipei," M.S. thesis, Dept. EMBA, National Cheng Kung Univ., Tainan, Taiwan, 2010

[21] E. Babbie, Survey Research Methods, 2nd ed., Belmont, CA: Wadsworth Publishing Co., 1990, ch. 5, pp. 65-100.

[22] J. B. Schreiber, A. Nora, F. K. Stage, E. A. Barlow, and J. King, "Reporting structural equation modeling and confirmatory factor analysis results: A review," The Journal of Educational Research, vol. 99, no. 6, pp. 323-338, Jul.- Aug. 2006.

[23] J. C. Nunnally, Psychometric Theory, 2nd ed., New York: McGraw-Hill, ch. 5, pp. 159-205, 1978.

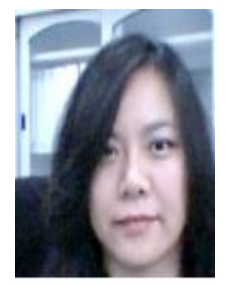

Shiau-Pei Shih was born in Kaohsiung city, Taiwan and her birth date is July 12th, 1968. Ms. Shih has earned one DBA degree from Northwestern Polytechnic University, California, USA in 2011 winter. The research field focuses on a cross-cultural marketing analysis between USA and Taiwan. Dr. Shih has two different majors of master degrees - one was MBA degree in project management from NPU, California, U.S. in 2009 and another was MED degree in MSCS from AU, Ohio, U.S.in 1995 as well.

Ms. Shih has been teaching in Far East University (FEU) more than 10 years in Taiwan and focusing on the marketing management, strategies and analysis. She used to be the Chief of Teaching Media Production Section in Far East University (FEU), Taiwan and a project manager in Sogo Bakery Co., now she is an assistant professor in Dept. Marketing and Logistics at FEU.

Dr. Shih is the member of PMI (Project Management Institute). Due to her abundant working experience, Dr. Shih leads students groups to win several awards of marketing proposal competition in Taiwan such as Bronze Medal of San John Award, Champion of 2013 Tic Taiwan Award, and Champion of 2013 Product Innovation and Commercialized Award. Her team has received many awards recognizing the excellence performance of the work. She also got twice the best Teaching Awards in FEU.

Szuchiang $\mathbf{Y u}$ is an administrative staff at Northwestern Polytechnic University (NPU), Fremont, California. He received his MSCS degree in 2001 from NPU and served as system administrator afterward. Mr. Yu was promoted and involved campus operations in daily work and was appointed as facility manager later. Now Mr. Yu serves as the director of Operations and IT Affairs in NPU and he is going to earn his MBA degree in spring of 2014 in the near future. 